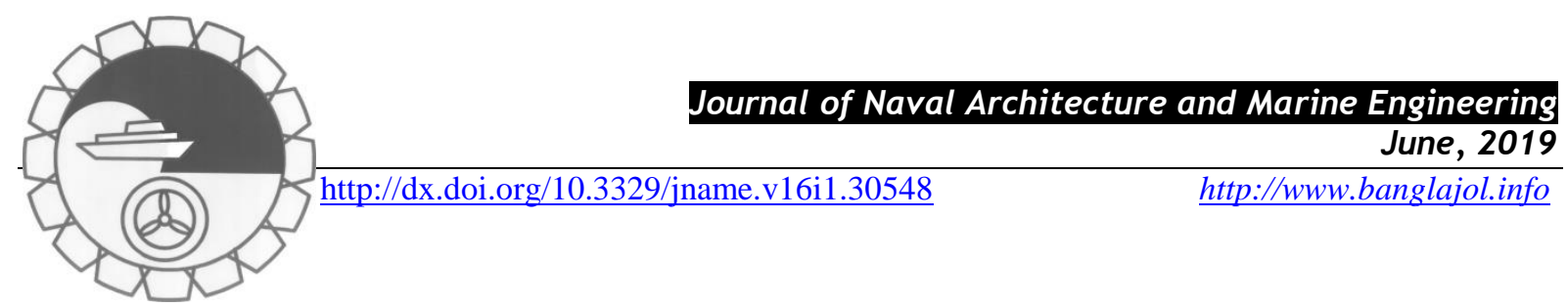

\title{
EFFECT OF NANOFLUID PROPERTIES AND MASS-FLOW RATE ON HEAT TRANSFER OF PARABOLIC-TROUGH CONCENTRATING SOLAR SYSTEM
}

\section{K. Islam ${ }^{1}$, M. Hasanuzzaman' ${ }^{2}$ N. A. Rahim ${ }^{3}$, A. Nahar ${ }^{4}$}

${ }^{1}$ UM Power Energy Dedicated Advanced Centre (UMPEDAC), Level 4, Wisma R\&D, University of Malaya, 59990 Kuala Lumpur, Malaysia, khairulbuet02@gmail.com

${ }^{2}$ UM Power Energy Dedicated Advanced Centre (UMPEDAC), Level 4, Wisma R\&D, University of Malaya, 59990 Kuala Lumpur, Malaysia, hasan@um.edu.my/hasan.buet99@gmail.com

${ }^{3}$ UM Power Energy Dedicated Advanced Centre (UMPEDAC), Level 4, Wisma R\&D, University of Malaya, 59990 Kuala Lumpur, Malaysia, nasrudin@um.edu.my

${ }^{4}$ Department of Computer Science, Faculty of Science and Information Technology, American International University Bangladesh, Dhaka 1229, afroza@ aiub.edu

\begin{abstract}
:
Sustainable power generation, energy security, and global warming are the big challenges to the world today. These issues may be addressed through the increased usage of renewable energy resources and concentrated solar energy can play a vital role in this regard. The performance of a parabolic-trough collector's receiver is here investigated analytically and experimentally using water based and therminol-VPlbased $\mathrm{CuO}, \mathrm{ZnO}, \mathrm{Al2O}$, TiO2, $\mathrm{Cu}$, Al, and $\mathrm{SiC}$ nanofluids. The receiver size has been optimized by a simulation program written in MATLAB. Thus, numerical results have been validated by experimental outcomes under same conditions using the same nanofluids. Increased volumetric concentrations of nanoparticle is found to enhance heat transfer, with heat transfer coefficient the maximum in $\mathrm{W}-\mathrm{Cu}$ and $\mathrm{VP} 1-\mathrm{SiC}$, the minimum in $\mathrm{W}-\mathrm{TiO} 2$ and $\mathrm{VP} 1-\mathrm{ZnO}$ at $0.8 \mathrm{~kg} / \mathrm{s}$ flow rate. Changing the mass flow rate also affects heat transfer coefficient. It has been observed that heat transfer coefficient reaches its maximum of $23.30 \%$ with SiC-water and $23.51 \%$ with VPI-SiC when mass-flow rate is increased in laminar flow. Heat transfer enhancement drops during transitions of flow from laminar to turbulent. The maximum heat transfer enhancements of $9.49 \%$ and $10.14 \%$ were achieved with Cu-water and VPI-SiC nanofluids during turbulent flow. The heat transfer enhancements of nanofluids seem to remain constant when compared with base fluids during either laminar flow or turbulent flow.
\end{abstract}

Keywords: Solar energy, parabolic trough concentrator, nanofluids, heat transfer coefficient.

\begin{tabular}{clcl}
\hline \multirow{2}{*}{ NOMENCLATURE } & \multicolumn{2}{c}{ Greek symbols } \\
$\mathrm{Nu}$ & Nusselt number & $\mu$ & viscosity \\
$\mathrm{Re}$ & Reynolds number & $\rho$ & Density \\
$\mathrm{Pr}$ & Prandtl number & \multicolumn{2}{c}{ Volume fraction } \\
$C_{p}$ & Specific heat & Subscripts & \\
$D$ & Receiver tube diameter & $b_{f}$ & Base fluid \\
$d$ & Nanoparticle diameter & $n_{f}$ & Nanofluid \\
$h$ & Heat transfer coefficient & $l$ & Layer \\
$K$ & Thermal conductivity & $p$ & Particle \\
$m$ & Mass flow rate & $f$ & Fluid \\
$r$ & Nanoparticle radius & \multicolumn{2}{c}{}
\end{tabular}

\section{Introduction}

Parabolic-trough concentrating solar (PTCS) system is one of the potential solar-energy harvesting systems wherein intense heating of the fluid is an important concern. Generally, heat-transfer enhancement techniques are based on structural variation; e.g., injection or suction of the fluid, implementation of an electrical or 1813-8535 (Print), 2070-8998 (Online) @ 2019 ANAME Publication. All rights reserved. Received on: Dec., 2016 
magnetic field, addition of a heat surface area, and vibration of the heated surface (Bergles, 1973; Zeinali et al., 2007). Enhancement of the thermal properties of the heat-transfer fluid is important in enhancing the heat transfer rate. Conventional heat transfer fluids (HTF) (i.e., water, oil, therminol VP1, ethylene glycol, etc.) have inherently lower thermal conductivity. Fluids with suspended solid nanoparticles of metals or metal oxides are reported to possess comparatively better thermo-physical properties (Abedin et al., 2013; Sani et al., 2010; Prasher et al., 2006; Prasher et al., 2006a; Saidur et al., 2012), which are the key factors to enhance overall system performance (Kwak et al., 2010; Javadi et al. 2013). Incorporation of nanoparticles provide the benefit of reducing heat transfer area of the heat exchanger through enhancing heat transfer capability of the working fluid (Sokhansefat, 2014). An investigation on the temperature dependence of thermal conductivity showed that over a temperature range of $21^{\circ} \mathrm{C}$ to $51{ }^{\circ} \mathrm{C}$, thermal conductivity of a nanofluid can improve from 2 -fold to even 4 fold of the original value (Das, 2003). A study of $35 \mathrm{~nm} \mathrm{Cu}$ /deionized-water nanofluid flowing in a tube at constant heat flux showed that increasing the volume concentrations of nanoparticles in water by $0.5 \%$ to $1.2 \%$ improves the Nusselt number of the nanofluid from 1.05 to 1.14 at the same flow rate (Xuan and Li, 2000). Use of 0.02 and 0.04 volume fractions of $\mathrm{Al}_{2} \mathrm{O}_{3}$ in water in a horizontal tube with uniform heat flux was found to enhance convective heat transfer coefficient by $9 \%$ and $15 \%$ respectively (Tsai et al., 2004; Akbari and Behzadmehr, 2007). Duangthongsuk (2009) found that $0.2 \% \mathrm{TiO} 2$ in water improves heat transfer coefficient by $6 \%$ to $11 \%$. It was observed that random dispersion of nanoparticles in a fluid enhances the fluid's convective heat transfer (Xuan and Li, 2003). Numerical analysis also shows increased heat transfer in the laminar flow of $\mathrm{Al}_{2} \mathrm{O}_{3}$ /ethylene glycol and $\mathrm{Al}_{2} \mathrm{O}_{3}$ /water nanofluids in a radial-flow system (Palm et al., 2004; Roy and Lajoie, 2004). Carbon nanohorn-based nanofluids have the potential to increase the efficiency and compactness of solar thermal systems by enhancing the sunlight absorption rate (Sani et al., 2011). Lenert (2012) investigated a 28 $\mathrm{nm}$ carbon-coated cobalt-therminol VP1 nanofluid-based volumetric solar receiver in high solar flux and high temperature. Authors found that the receiver's efficiency was increase when both the nanofluid column height and the incident solar flux increased. Lu et al. (2011) experimented with water and water-CuO nanofluid in a high-temperature evacuated tubular solar collector and found 30\% improvement of the evaporating heat transfer coefficient due to water-CuO.

Kasaeian et al. (2012) investigated synthetic oil- $\mathrm{Al}_{2} \mathrm{O}_{3}$ nanofluid in the receiver tube of a parabolic-trough collector and found that heat-transfer coefficient of the nanofluid was increased with increased concentration of the nanoparticles. It has been noticed by several researchers that use of nanofluid improve the solar absorption rate of the solar receivers. Saidur et al. (2012) and Taylor et al. (2011) found absorption of as high as 95\% solar radiation when nanofluids were used in the receivers. Dnyaneshwar et al. (2014) conducted an experiment on parabolic-trough receiver with and without tape inserts, and with water or silver-nanofluid. Using tap inserts and of water/silver-nanofluid was found to increase Nusselt number by 1.25 to 2.10 times and enhance efficiency by $135 \%-205 \%$.

Tagle-Salazar et al. (2018) proposed a thermal model of parabolic trough solar collectors for heating applications using nanofluid as heat transfer fluid. The Engineering Equation Solver (EES) was used as software to simulate the model and model predictions were found to be in good agreement with the experimental results. Kasaiean et al. (2018) devised a solar thermal heat transfer network for a parabolic trough collector is introduced, in which a nanofluid is considered as the heat transfer medium. The finite difference scheme (FDM) was adopted as the approach, and a code was created in MATLAB. Authors noticed an increase in radiant loss from 26.5 to $57.3 \mathrm{~W} / \mathrm{m}$ in the range of 30 to $100^{\circ} \mathrm{C}$.

Enhanced heat transfer rate in a parabolic trough solar receiver has been obtained by Chang et al. (2018) by inserting rods and using molten salt as heat transfer fluid. O'Keeffe et al. (2018) modelled the efficiency of a nanofluid-based direct absorption parabolic trough solar collector and found that the nanofluid's temperature rise is linear as it flows through the receiver. Optical and thermal analysis of a parabolic trough solar collector for production of thermal energy in different climates in Iran has been conducted by Marefati et al. (2018), wherein authors observed that Shiraz city is the best region for solar concentrating system with an average annual thermal efficiency of $13.91 \%$ and annual useful energy of $2213 \mathrm{kWh} / \mathrm{m}^{2}$.

Okonkwo et al. (2018) analysed the thermal performance of a parabolic trough collector using water based green-synthesized nanofluids and found that heat transfer performance of the nanofluids shows a mean enhancement in heat transfer coefficient of $128 \%$ and $138 \%$. Very recently, numerical analysis of magnetic field effects on the heat transfer enhancement in ferrofluids for a parabolic trough solar collector has been carried out by Khosravi et al. (2019), wherein authors noticed that using magnetic field can increase the local heat transfer coefficient of the collector tube, thermal efficiency as well as output temperature of the collector. 
Literature review shows that although many research has been conducted to explore the applicability and advantage of nanofluids in enhancing heat transfer very few researches focused their application in parabolic trough solar concentrating systems (PTCS). Hence, there is still scope to work with fluid flow and variation of volumetric concentration of nanoparticles in nanofluid in heat transfer enhancement thereby performance improvement of PTCS. In this article, water and therminol VP1 were chosen as the base fluids along with seven nanoparticles $\left(\mathrm{CuO}, \mathrm{ZnO}, \mathrm{Al}_{2} \mathrm{O}_{3}, \mathrm{TiO}_{2}, \mathrm{Cu}, \mathrm{Al}, \mathrm{SiC}\right)$, to investigate the effects of nanofluid mass-flow rate and volumetric concentration of nanoparticles on the performance of a parabolic trough solar concentrator system.

\section{Methodology}

\subsection{Model development}

A model of the parabolic-trough concentrator system (PTCS) is shown in Fig. 1. The effect of nanofluid mass flow rate and volumetric concentration of nanoparticles on the performance of parabolic solar receiver has been investigated using the same design of PTC system. As can be seen from the figure solar insolation approaching the mirror is concentrated on the receiver positioned alongside the focused line and heats up the heat transfer fluid (HTF) contained in the receiver tube to an elevated temperature.

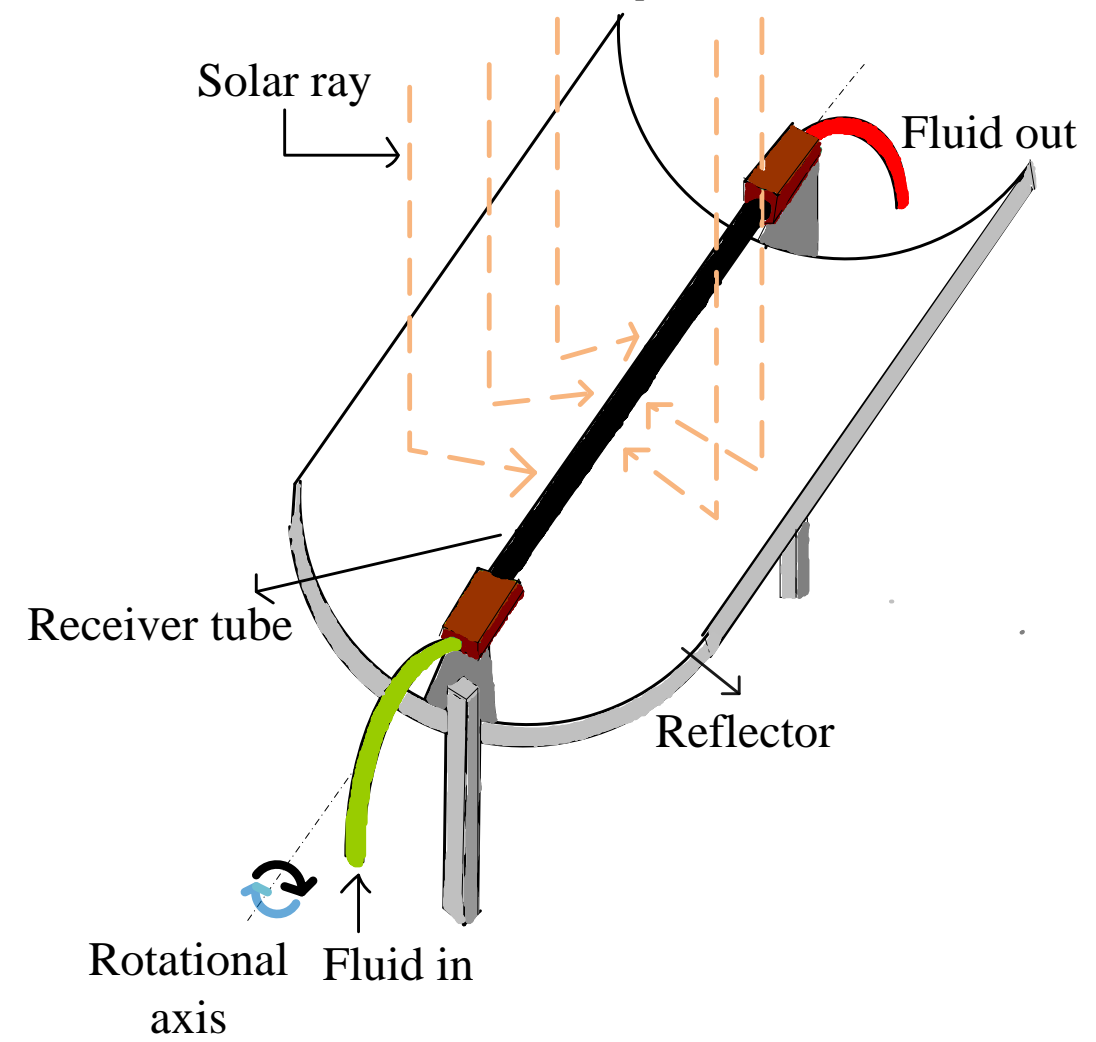

Fig. 1: Parabolic-trough concentrating solar (PTCS) system (Islam et al., 2015)

The design parameters and dimensions of the parabolic-trough system are as listed in Table 1. Table 2 lists the thermo-physical properties of water, therminol VP1, and selected nanoparticles.

Table 1: Dimensions of the system setup and operating conditions

\begin{tabular}{|c|c|}
\hline Description & Specifications \\
\hline \multicolumn{2}{|l|}{ Parabolic reflector: } \\
\hline Length & $2.0 \mathrm{~m}$ \\
\hline Aperture & $1.5 \mathrm{~m}$ \\
\hline Focus & $0.375 \mathrm{~m}$ \\
\hline \multicolumn{2}{|l|}{ Receiver tube: } \\
\hline Length & $2.0 \mathrm{~m}$ \\
\hline
\end{tabular}

Effect of nanofluid properties and mass-flow rate on heat transfer of parabolic-trough concentrating solar system 


\begin{tabular}{ll}
\hline Inner diameter & $48 \mathrm{~mm}$ \\
Tube thickness & $4 \mathrm{~mm}$ \\
Mass flow rate & 0.01 to $1.05 \mathrm{~kg} / \mathrm{s}$ \\
Solid volume concentrations & up to $3 \%$ \\
\hline
\end{tabular}

Table 2: Thermo-physical properties of the base fluids and nanoparticles

\begin{tabular}{|c|c|c|c|c|}
\hline Material & $\mathbf{K}\left(\mathbf{W} /\left(\mathbf{m}^{2} . \mathbf{K}\right)\right.$ & $\begin{array}{l}\text { Density } \\
\left(\mathrm{kg} / \mathrm{m}^{3}\right)\end{array}$ & $\begin{array}{l}\mathbf{C p} \\
(\mathrm{J} / \mathrm{kg} . \mathrm{K})\end{array}$ & Reference \\
\hline Water $\left(34^{\circ} \mathrm{C}\right)$ & 0.652 & 994 & 4174 & (Holman, 1997) \\
\hline $\begin{array}{l}\text { Therminol VP-1 } \\
\left(34^{\circ} \mathrm{C}\right)\end{array}$ & 0.135 & 1053 & 1590 & $\begin{array}{l}\text { (www.therminol.com/pages/bulletins } \\
\text { /therminol_vp1.pdf) }\end{array}$ \\
\hline $\mathrm{CuO}(40 \mathrm{~nm})$ & 76 & 6320 & 565.11 & $\begin{array}{l}\text { (Eastman et al., 1997; Kole and Dey, } \\
\text { 2012) }\end{array}$ \\
\hline $\mathrm{TiO}_{2}(25 \mathrm{~nm})$ & 8.4 & 4157 & 710 & $\begin{array}{l}\text { (Eastman et al., 1997; Kole and Dey, } \\
\text { 2012) }\end{array}$ \\
\hline $\mathrm{Al}_{2} \mathrm{O}_{3}(40 \mathrm{~nm})$ & 40 & 3960 & 773 & (Sarkar, 2011; Kamyar et al., 2012) \\
\hline $\mathrm{Al}(80 \mathrm{~nm})$ & 237 & 2700 & 904 & (Sarkar, 2011; Kamyar et al., 2012) \\
\hline $\mathrm{Cu}(35 \mathrm{~nm})$ & 401 & 890 & 385 & (Sarkar, 2011; Kamyar et al., 2012) \\
\hline $\mathrm{ZnO}(40 \mathrm{~nm})$ & 21 & 5610 & 523.25 & $\begin{array}{l}\text { (Eastman et al., 1997; Kole and Dey, } \\
\text { 2012) }\end{array}$ \\
\hline $\mathrm{SiC}(16 \mathrm{~nm})$ & 150 & 3370 & 1340 & $\begin{array}{l}\text { (Timofeeva et al.; 2010; Cengel, } \\
\text { 2007; Pak and Cho, 1998) }\end{array}$ \\
\hline
\end{tabular}

\subsection{Formulation of the heat transfer mechanism}

The heat transfer coefficient of the nanofluid of the parabolic-trough receiver tube was calculated as follows (Brinkman, 1952):

$$
h_{n f}=\frac{N u_{n f} K_{n f}}{D_{i}}
$$

The Nusselt number $N u_{n f}$ was calculated for laminar and turbulent flows as follows (Yu and Choi, 2003):

$N u_{n f}=4.364$

with the constant heat flux considered and $R e_{n f} \leq 2300$.

$$
N u_{n f}=0.023 \operatorname{Re}_{n f}{ }^{0.8} \operatorname{Pr}_{n f}{ }^{0.4}
$$

where $2300<R e_{n f}<1.25 \times 10^{5}$ and $0.6<P r_{n f}<100$.

In Equation (3), $R e_{n f}$ and $P r_{n f}$ are the nanofluid's Reynolds and Prandtl numbers respectively; those were calculated as follows (Brinkman, 1952):

$$
\begin{aligned}
& \operatorname{Re}_{n f}=\frac{4 m_{n f}}{\pi D_{i} \mu_{n f}} \\
& \operatorname{Pr}_{n f}=\frac{C_{P n f} \mu_{n f}}{K_{n f}}
\end{aligned}
$$

The thermo-physical properties of the nanofluids (density, viscosity, specific heat, and thermal conductivity) were calculated with the following correlations (Yu and Choi, 2003; Shahrul et al., 2014; Leong et al., 2006):

$$
\begin{aligned}
& \rho_{n f}=\phi \rho_{p}+(1-\phi) \rho_{b f} \\
& \mu_{n f}=\mu_{b f}(1-\phi)^{-2.5} \\
& C_{P n f}=\frac{\phi \rho_{p} C_{P p}+(1-\phi) \rho_{b f} C_{P b f}}{\rho_{n f}}
\end{aligned}
$$


The nanofluids' effective thermal conductivity was calculated as follows (Hong and Yang, 2005):

$$
\text { Keff }=\frac{\left(K_{p}-K_{l}\right)\left(2 \beta_{1}{ }^{3}-\beta^{3}-1\right) \phi K_{l}+\left(K_{p}+2 K_{l}\right)\left[\left(K_{l}-K_{f}\right) \phi \beta^{3}+K_{f}\right] \beta_{1}{ }^{3}}{\left(K_{p}+2 K_{l}\right) \beta_{1}{ }^{3}-\left(K_{p}-K_{l}\right)\left(\beta_{1}{ }^{3}+\beta^{3}-1\right) \phi}
$$

Equation (9) considers the effects of particle size, interfacial layer, and $\beta_{1}=1+(h / d) \beta, \beta=1+h / r$. The rheological and physical properties were calculated at the inlet temperature. The Nusselt number and convective heattransfer coefficient were calculated at constant and various mass-flow rates and various volumetric concentrations $(0.025 \%$ to $3 \%)$.

\section{Results and Discussion}

\subsection{Validation of the theoretical PTCS model}

The theoretical model of the parabolic trough concentrator as described in the preceding section has been validated with the results obtained experimentally by the authors (Islam, 2016). For validation purpose, theoretical values two performance parameters, viz., heat gain and thermal efficiency have been compared with those obtained experimentally (refer to Fig. 2 and Fig. 3). Although experimental outcomes in all cases show relatively declining trend as compared to the corresponding theoretical values it may easily be ignored keeping in the mind that many external factors affect experimental results. Thus, it may be concluded that though there are discrepancies in terms of quantitative comparison the present theoretical model is qualitatively well validated by experimental results. Hence, further analysis using this theoretical model will be quite credible.

\subsection{Nanofluid at constant mass-flow rate}

The effects of the water-based nanofluids and therminol-VP1-based nanofluids with $2.5 \%$ nanoparticles at constant flow rate $(0.8 \mathrm{~kg} / \mathrm{s})$ are presented and discussed in this section.

\subsubsection{Effect on heat transfer coefficient}

The effects of nanoparticles on heat transfer along the receiver tube are shown in Fig. 4 and 5, respectively for water and therminol-VP1-based nanofluids. The enhanced heat-transfer coefficients at $0.8 \mathrm{~kg} / \mathrm{s}$ mass flow rate were found to be $4.30 \%, 3.36 \%, 5.89 \%, 2.71 \%, 9.49 \%, 7.95 \%$, and $7.97 \%$, respectively for $\mathrm{W}-\mathrm{CuO}, \mathrm{W}-\mathrm{ZnO}$, $\mathrm{W}-\mathrm{Al}_{2} \mathrm{O}_{3}, \mathrm{~W}-\mathrm{TiO}_{2}, \mathrm{~W}-\mathrm{Cu}, \mathrm{W}-\mathrm{Al}$, and $\mathrm{W}-\mathrm{SiC}$ nanofluids. With therminol-VP1 nanofluids, the enhanced heattransfer coefficients at the same mass-flow rate were $6.46 \%, 6.34 \%, 8.20 \%, 7.08 \%, 9.78 \%, 9.23 \%$, and $10.14 \%$, respectively for $\mathrm{VP} 1-\mathrm{CuO}, \mathrm{VP} 1-\mathrm{ZnO}, \mathrm{VP} 1-\mathrm{Al}_{2} \mathrm{O}_{3}, \mathrm{VP} 1-\mathrm{TiO}_{2}, \mathrm{VP} 1-\mathrm{Cu}, \mathrm{VP} 1-\mathrm{Al}$, and $\mathrm{VP} 1-\mathrm{SiC}$. The results prove that the highest heat-transfer coefficient among water-based nanofluids is in $\mathrm{W}-\mathrm{Cu}$ nanofluid, whereas the maximum heat transfer coefficient among therminol-VP1-based nanofluids is in VP1-SiC.

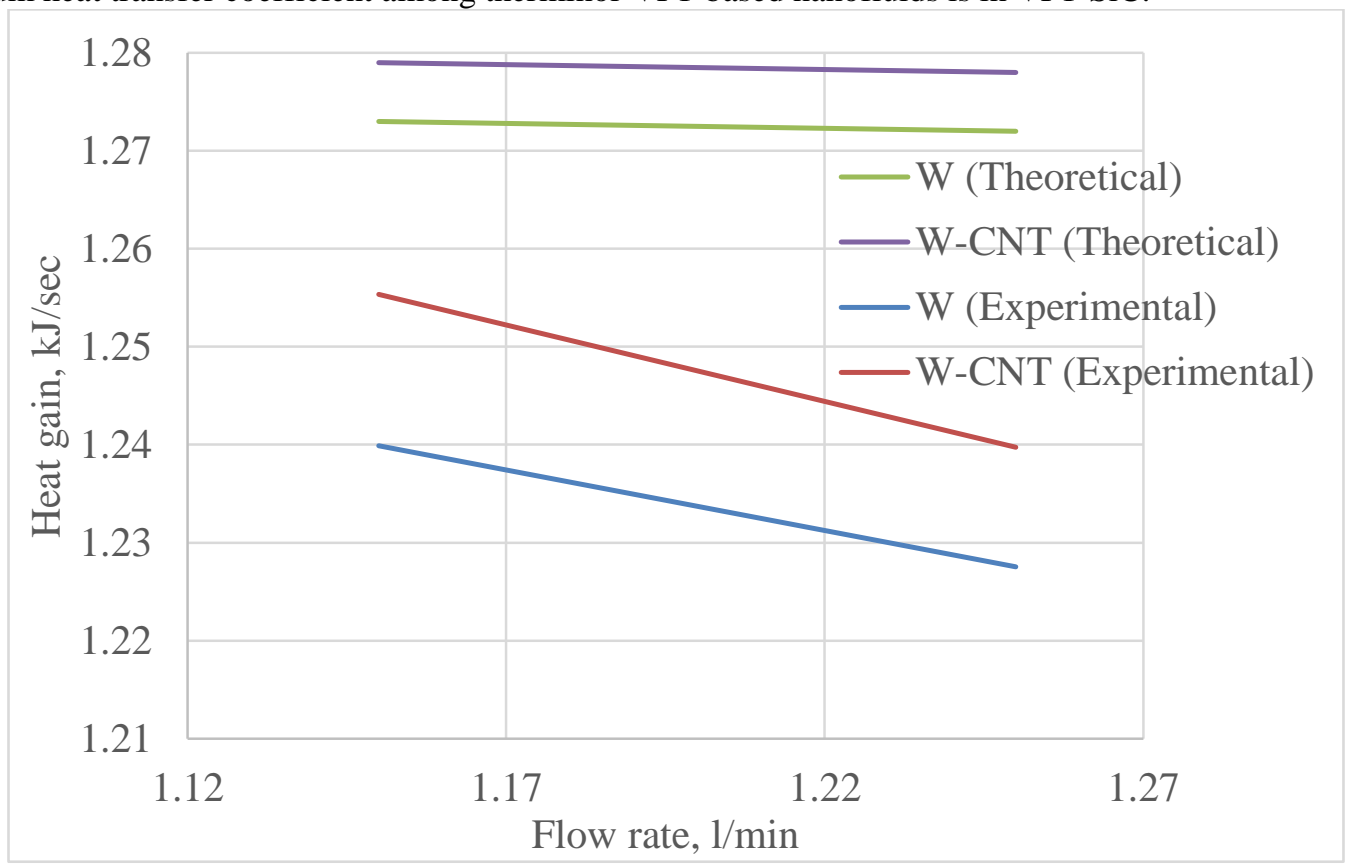

Fig. 2: Heat gain as a function of flow rate of working fluid (Irradiation $640 \mathrm{~W} / \mathrm{m}^{2}$ ) 


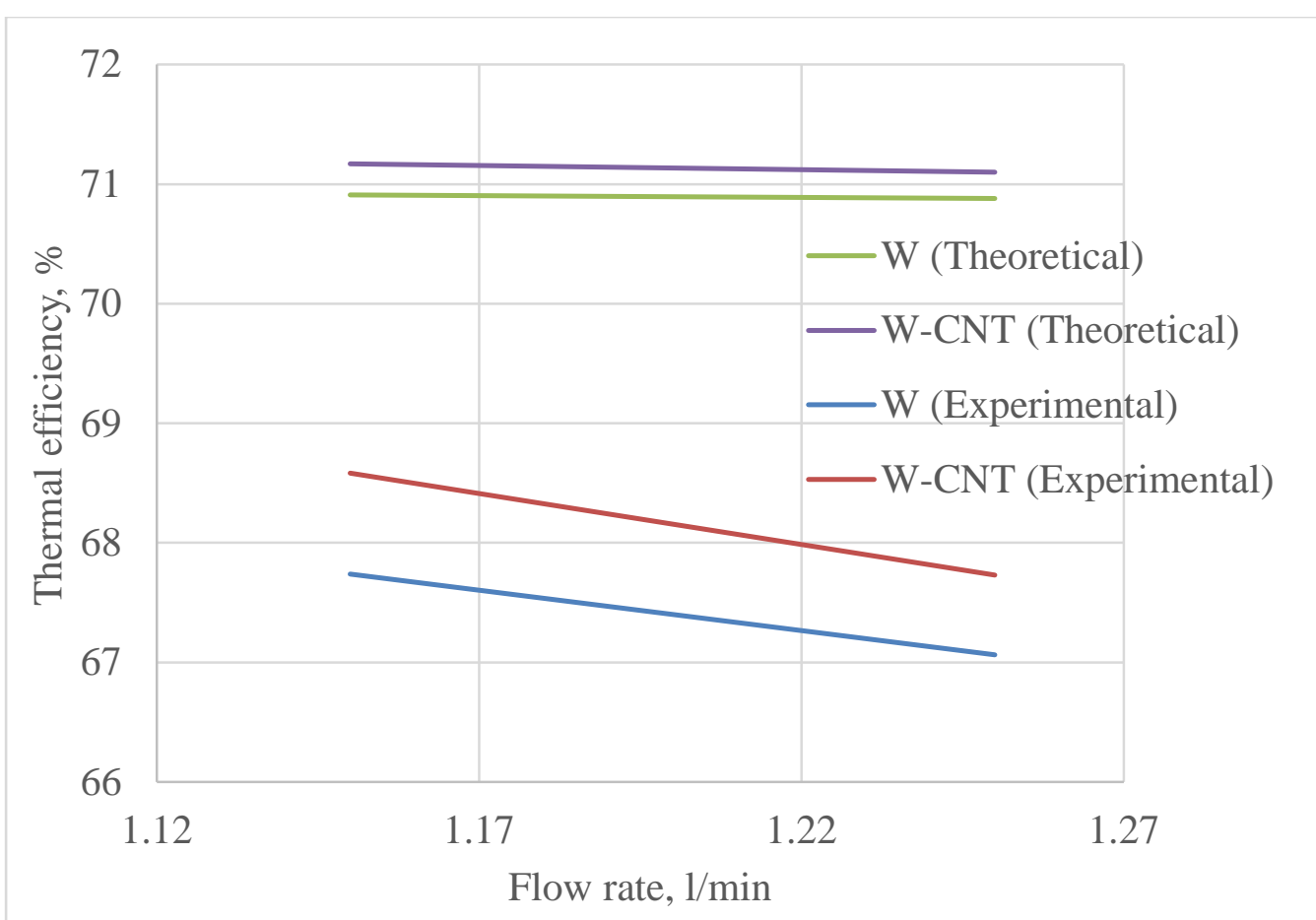

Fig. 3: Thermal efficiency as a function of flow rate of working fluid (Irradiation $640 \mathrm{~W} / \mathrm{m}^{2}$ )

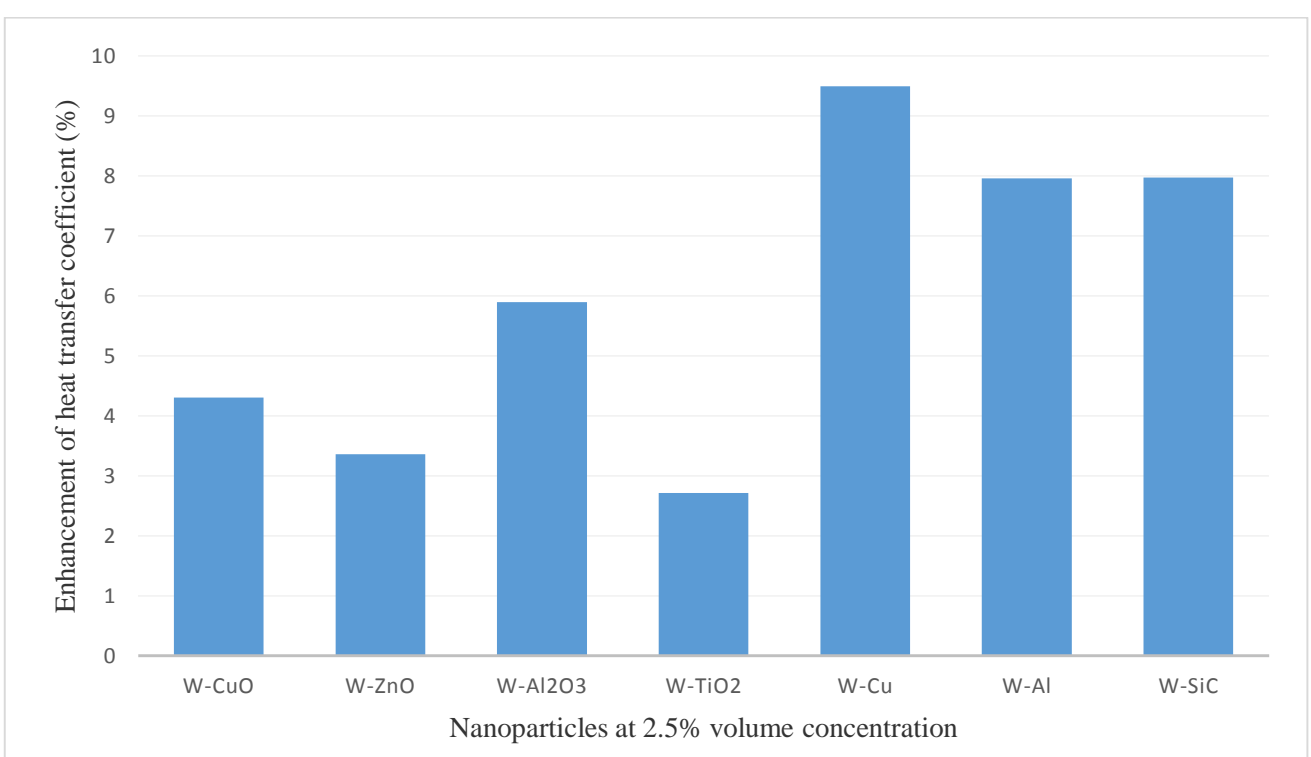

Fig. 4: Enhanced heat-transfer coefficient in water-based nanofluids at $0.8 \mathrm{~kg} / \mathrm{s}$ mass flow rate

The specific heat of nanofluid is the main reason. $\mathrm{Cu}$ and $\mathrm{SiC}$ have higher specific heat than other nanoparticles. However, the thermal conductivities of $\mathrm{W}-\mathrm{Cu}$ and $\mathrm{W}-\mathrm{SiC}$ are 0.7688 and 0.7689 respectively, almost the same and the maximum among water-based nanofluids. Also, VP1-Cu and VP1-SiC have the same thermal conductivity ( 0.166 each). The specific heat of $\mathrm{W}-\mathrm{Cu}$ nanofluid is $3.46 \%$ higher than that of $\mathrm{W}-\mathrm{SiC}$ nanofluid, although the specific heat of $\mathrm{SiC}$ particle is $71.27 \%$ higher than that of $\mathrm{Cu}$ particle. The specific heat of water is also comparatively higher. The higher-density $\mathrm{SiC}$ particles thus dominate, leading to a comparatively higherdensity nanofluid $\left(1053 \mathrm{~kg} / \mathrm{m}^{3}\right.$, which is $5.88 \%$ higher than the density of $\left.\mathrm{W}-\mathrm{Cu}\right)$, and produce $1138.5 \mathrm{~W} /\left(\mathrm{m}^{2} . \mathrm{K}\right)$ heat transfer coefficient that is lower than that of $\mathrm{W}-\mathrm{Cu}\left(1154.6 \mathrm{~W} /\left(\mathrm{m}^{2} . \mathrm{K}\right)\right.$, the maxima among water based nanofluids). On the other hand, although the density of VP1-SiC is $5.58 \%$ higher than that of VP1-Cu, VP1-SiC is the one with the maximum heat-transfer coefficient. Here, the nanoparticle's specific heat is the cause of the 
increased specific heat of the nanofluid and the consequent increased heat-transfer coefficient. The specific heat of VP1-SiC nanofluid is higher than that of other therminol-VP1-based nanofluids which produces the highest heat-transfer coefficient $354.6 \mathrm{~W} /\left(\mathrm{m}^{2} . \mathrm{K}\right)$ and thus enhances heat transfer coefficient to the maxima $(10.14 \%)$.

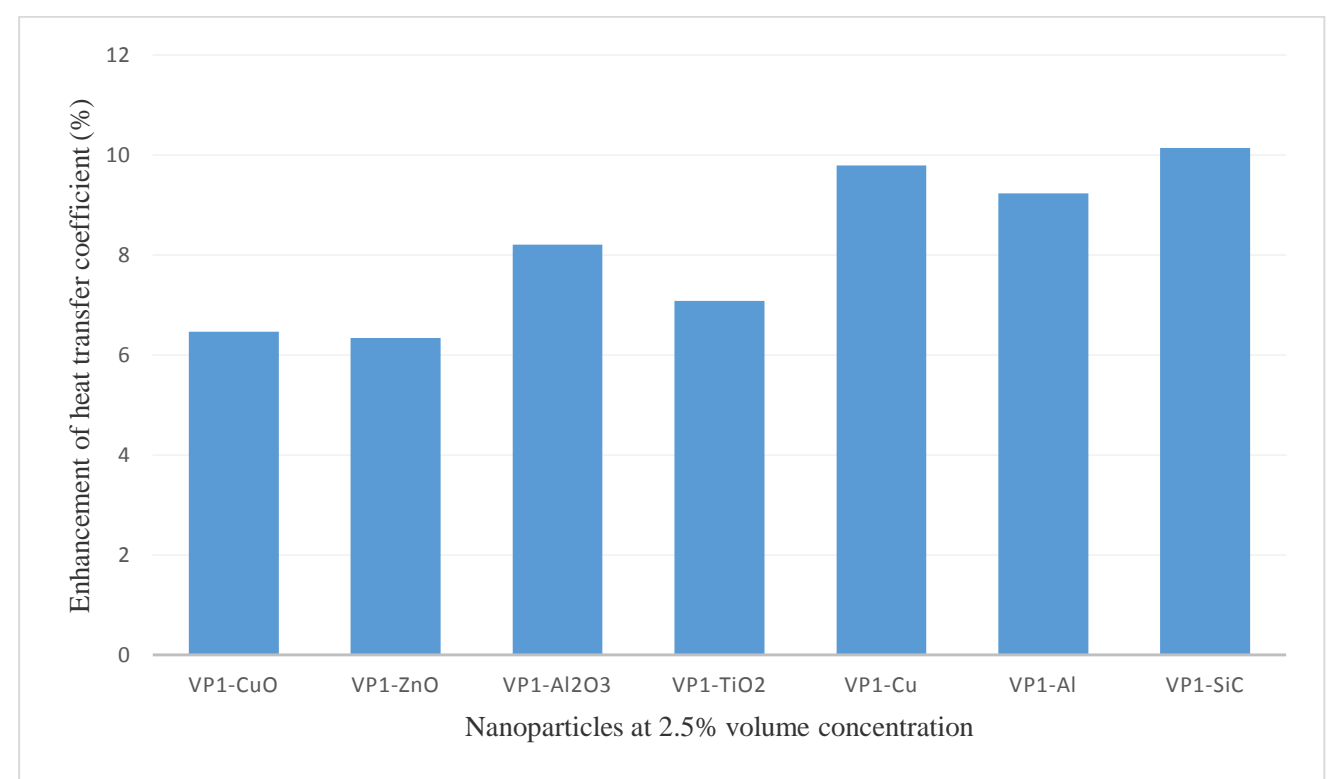

Fig. 5: Enhanced heat-transfer coefficient in therminol-VP1-based nanofluids at $0.8 \mathrm{~kg} / \mathrm{s}$ mass flow rate

Other water-based nanofluids differ in their thermal conductivities, so thermal conductivity is a crucial element here. Nanofluids with higher thermal conductivity produce higher heat transfer coefficients, consequent higher heat transfer enhancement. $\mathrm{W}-\mathrm{TiO}_{2}$ nanofluid was found to have the lowest enhancement of heat transfer coefficient, owing to its low thermal conductivity (the lowest), although it's specific heat capacity is $4.44 \%$ and $3.28 \%$ higher than that of $\mathrm{W}-\mathrm{CuO}$ and $\mathrm{W}-\mathrm{ZnO}$ nanofluids respectively.

All therminol-VP1-based nanofluids have almost the same thermal conductivities. As with VP1-Cu and VP1$\mathrm{SiC}$ nanofluids, specific heat capacity is the main cause for the increased heat-transfer coefficients in the other therminol-VP1-based nanofluids. Nanofluids with higher specific heat produce higher heat transfer coefficients and thus cause higher enhancement of heat transfer coefficients. But the VP1-ZnO causes the lowest enhancement of fig heat transfer although VP1-CuO possesses the lowest specific heat capacity (1453.3 $\mathrm{j} /(\mathrm{kg} . \mathrm{K}))$. It is due to the both thermal conductivity $21 \mathrm{~W} /\left(\mathrm{m}^{2} \cdot \mathrm{K}\right)$ and specific heat $523.25 \mathrm{j} /(\mathrm{kg} . \mathrm{K})$ of $\mathrm{ZnO}$ nanoparticle, respectively $72.4 \%$ and $7.4 \%$ lower than that of $\mathrm{CuO}$.

\subsection{Nanofluids at different mass flow rates}

In this section the effects of nanofluids on heat transfer coefficient at various mass flow rates have been discussed. The nanofluids contain $2.5 \%$ nanoparticles on volumetric basis.

\subsubsection{Effect on the heat transfer coefficient}

The enhanced heat-transfer coefficients of water and therminol-VP1-based nanofluids are respectively as presented in Figures 6 and 7. The figures show that during laminar flow, enhancement of heat transfer coefficients does not change with change of the mass flow rate. In the transition period, the heat transfer coefficients drop until turbulent flow is reached. During turbulent flow, enhancement of the heat transfer coefficient remains constant while the mass-flow rate changed (because during laminar or turbulent flow, heat transfer enhances at the same rate in base fluid and nanofluids). Figure 4 shows 21.85\%, 19.01\%, 22.25\%, $15.33 \%, 23.00 \%, 22.70 \%$, and $23.30 \%$ enhanced heat-transfer coefficients in laminar flow, and $4.30 \%, 3.36 \%$, $5.89 \%, 2.71 \%, 9.49 \%, 7.95 \%$, and $7.97 \%$ in turbulent flow, both respectively in $\mathrm{W}-\mathrm{CuO}, \mathrm{W}-\mathrm{ZnO}, \mathrm{W}-\mathrm{Al}_{2} \mathrm{O}_{3}, \mathrm{~W}-$ $\mathrm{TiO}_{2}, \mathrm{~W}-\mathrm{Cu}, \mathrm{W}-\mathrm{Al}$, and W-SiC nanofluids. Figure 6 shows 22.94\%, 22.22\%, 22.63\%, 20.96\%, 23.08\%, $23.04 \%$, and $23.51 \%$ enhanced heat-transfer coefficients in laminar flow, and $6.46 \%, 6.34 \%, 8.20 \%, 7.08 \%$, $9.78 \%, 9.23 \%$, and $10.14 \%$ in turbulent flow, both respectively for $\mathrm{VP} 1-\mathrm{CuO}, \mathrm{VP} 1-\mathrm{ZnO}, \mathrm{VP} 1-\mathrm{Al}_{2} \mathrm{O}_{3}, \mathrm{VP} 1-$ 
$\mathrm{TiO}_{2}$, VP1-Cu, VP1-Al, and VP1-SiC nanofluids. During laminar flow and according to Equation (1), thermal conductivity is the main enhancer of heat transfer coefficient (because Nusselt number is constant in all the nanofluids, as shown by Equation (2)). W-SiC and VP1-SiC nanofluids, with their maximum thermal conductivities, provide maximum enhancement of the heat transfer coefficient. The heat transfer coefficient of other nanofluids, too, have been found to depend on their thermal conductivities. During turbulent flow, the thermal conductivity of a nanofluid enhances the heat transfer coefficient of water-based nanofluids, with W-Cu and $\mathrm{W}-\mathrm{TiO}_{2}$ respectively having the maximum and the minimum enhancement of heat transfer coefficient. In therminol VP1-based nanofluids, however, specific heat instead is the main enhancer of heat transfer, with VP1$\mathrm{SiC}$ and VP1-ZnO respectively having the maximum and the lowest heat transfer coefficient.

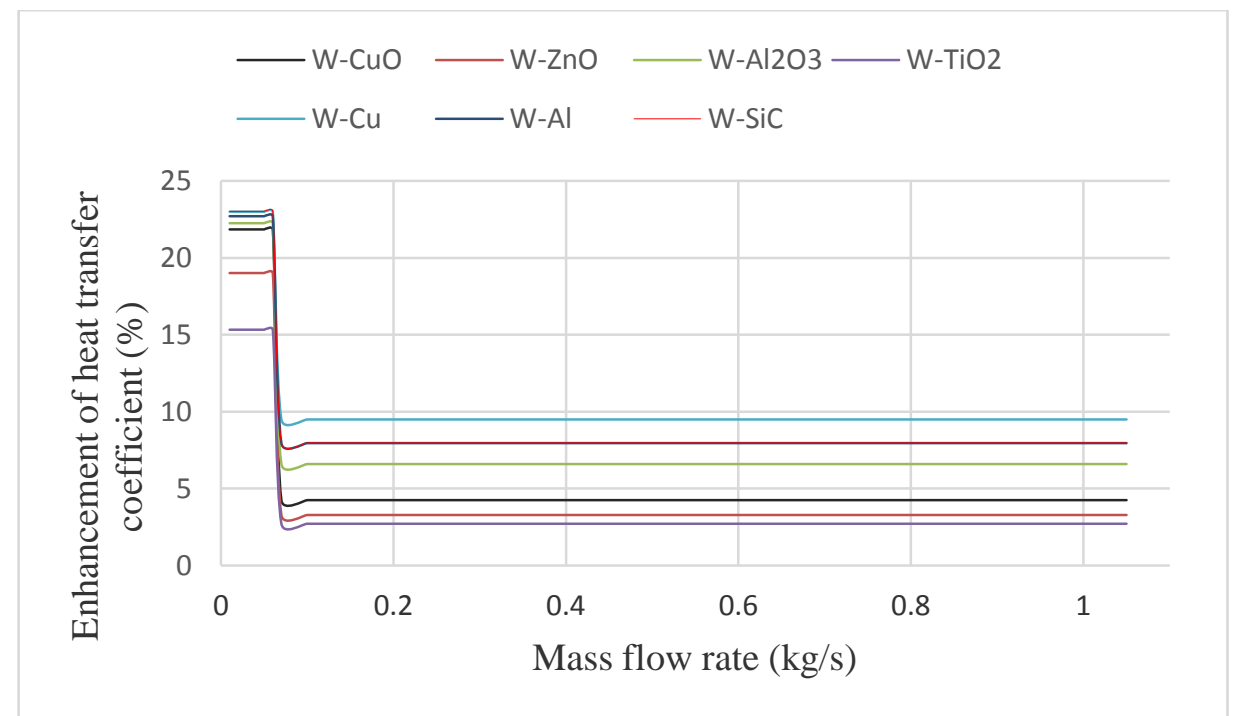

Fig. 6: Enhancement of heat transfer coefficient in water-based nanofluids at various mass-flow rates

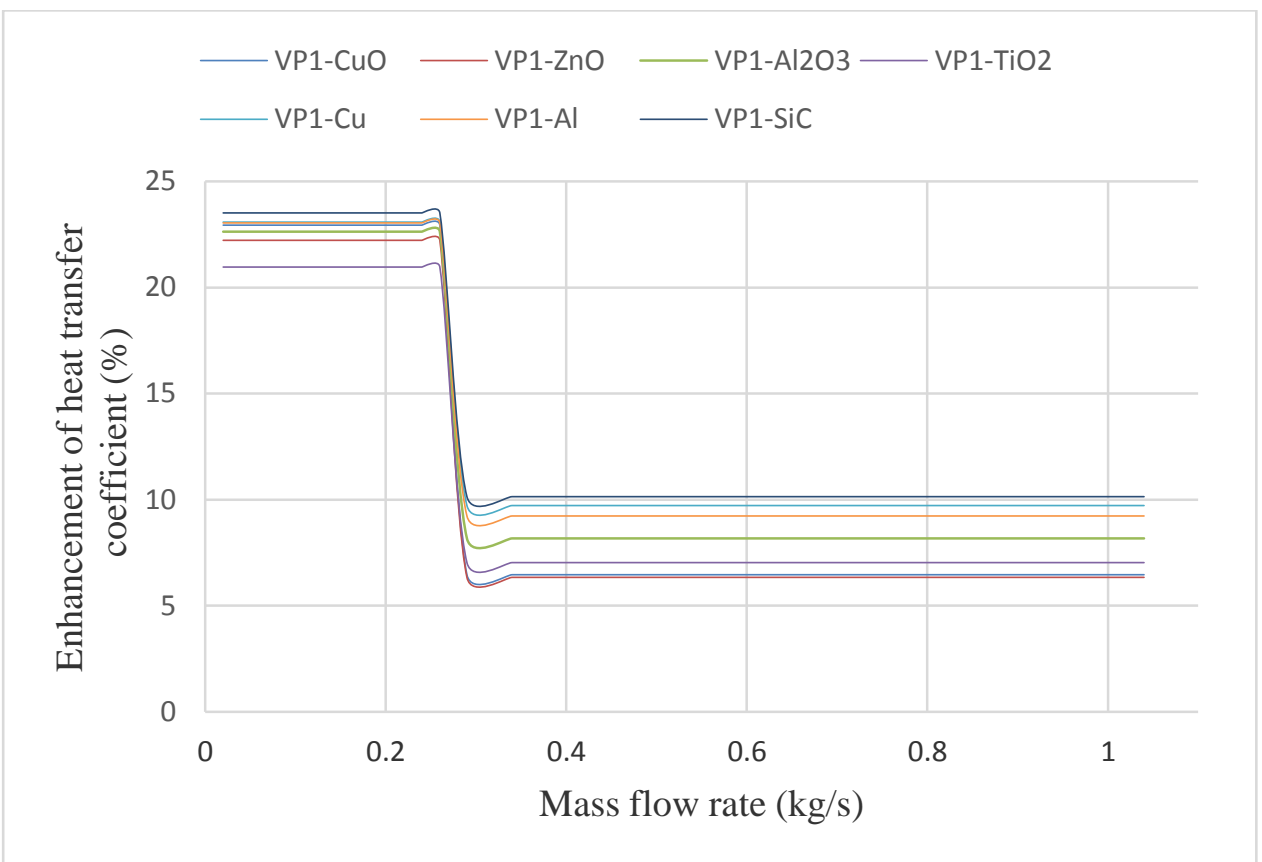

Fig. 7: Enhancement of heat transfer coefficient in therminol-VP1-based nanofluids at various mass-flow rates

\subsection{Effect of volumetric concentrations of the nanoparticles}

Figs. 8 and 9 illustrate the effects of the volumetric concentrations of the nanoparticles on the heat transfer coefficient. They show that adding low volumetric concentrations $(0.025 \%$ to $3 \%)$ of nanoparticles (except below $0.05 \%$ ) to base fluids significantly enhances the heat transfer coefficient. This indicates that the addition 
of nanoparticles improves the heat absorption of the heat-transfer fluid, increasing its temperature. Generally, high thermal conductivity in a nanoparticle increases the heat transfer coefficient of a fluid. The Brownian motion in nanoparticles with a large surface area for molecular collisions enhances thermal conductivity. High volumetric concentrations of nanoparticles cause high momentum, which carries and transfers thermal energy more efficiently and at a greater distance inside the base fluid, thus enhancing the heat-transfer rate of the fluid [39].

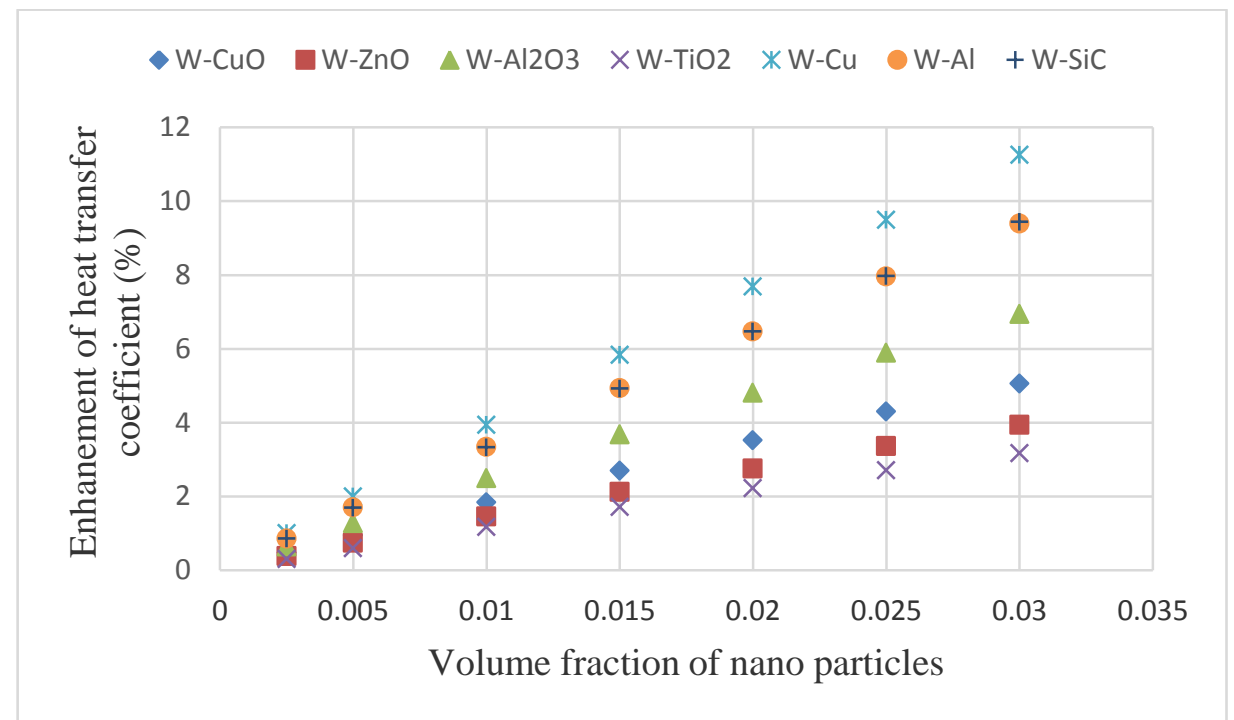

Fig. 8: Enhancement of heat transfer coefficient in water-based nanofluids with various volumetric concentrations of nanoparticles

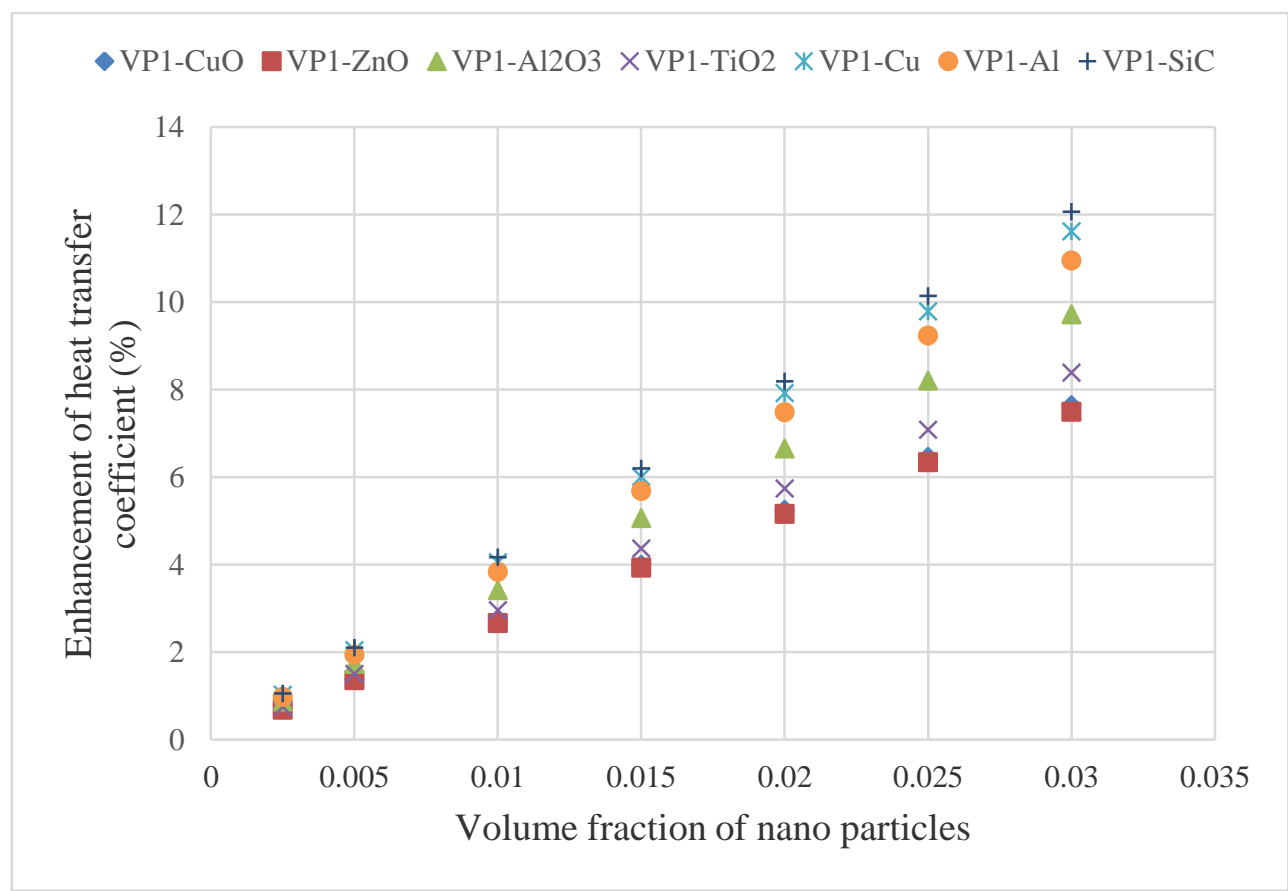

Fig. 9: Enhancement of heat transfer coefficient in therminol-VP1-based nanofluids with various volumetric concentrations of nanoparticles

\section{Conclusions}

The effect of mass flow rate of heat transfer fluid and the volumetric concentration of nanoparticle on the heat transfer rate and system performance of a parabolic trough concentrating system (PTCS) has been investigated in the present research. The conclusions of the research outcomes are given as below: 
- At constant mass flow rate of $0.8 \mathrm{~kg} / \mathrm{s}$, the maximum enhancement of the heat transfer coefficient is $9.49 \%$ in $\mathrm{W}-\mathrm{Cu}$ and $10.14 \%$ in $\mathrm{VP} 1-\mathrm{SiC}$.

- During laminar flow, the maximum enhancement of the heat transfer coefficient is $23.3 \%$ in W-SiC and $23.51 \%$ in VP1-SiC.

- In laminar flow, the thermal conductivity of a nanofluid acts as the main enhancer of heat transfer rate.

- Enhancement in heat transfer drops during transition flow

- During turbulent flow, the maximum enhancement of the heat transfer coefficient is $9.49 \%$ in W-Cu and $10.14 \%$ in VP1-SiC;

- Specific heat is the main enhancer of heat transfer, as in W-Cu, W-SiC, and all therminol-VP1-based nanofluids; in other water-based nanofluids, thermal conductivity is mainly responsible.

- During laminar flow or fully developed turbulent flow, enhancement of the heat transfer remains constant due to enhancement of the heat transfer coefficients at the same rate in base fluid and nanofluids.

- Increasing the volumetric concentration of a nanofluid increases its heat transfer coefficient.

The outcomes of the present research are crucial for both industrial applications such as space heating to electricity generation and future research works. The real-world concentrating solar systems can readily apply the findings by making use of the nanofluids as recommended in this research findings, which will facilitate to improve the system performance as well as ensure commercial applicability of these systems.

\section{Acknowledgements}

Authors acknowledge the financial support from the University Malaya Research Grant scheme (Project No: RP016A-15SUS) to carry out this research.

\section{References}

Abedin, Z., Alim, M.A., Saidur, R., Islam, M.R., Rashmi, W., Mekhiler, S., and Wadi, A. (2013): Solar Energy Harvesting with the Application of Nanotechnology, Renewable and Sustainable Energy Reviews, Vol. 26, pp. 837-852. https://doi.org/10.1016/j.rser.2013.06.023

Akbari, M., and Behzadmehr, A. (2007): Developing Mixed Convection of a Nanofluid in a Horizontal Tube with Uniform Heat Flux Number Methods, International Journal of Numerical Methods for Heat \& Fluid Flow, Vol. 17, No. 6, pp. 566-586. https://doi.org/10.1108/09615530710761216

Bergles, A.E. (1973): Recent Development in Convective Heat Transfer Augmentation, Applied Mechanics Reviews, Vol. 26: pp. 675-682.

Brinkman, H.C. (1952): The Viscosity of Concentrated Suspensions and Solutions, The Journal of Chemical Physics, Vol. 20, pp. 571. https://doi.org/10.1063/1.1700493

Cengel, Y. (2007): Heat and Mass Transfer-A Practical Approach, 3rd ed. Tata Mcgraw-Hill, India.

Chang, C., Sciacovelli, A., Wu, Z., Li, X., Li, Y., Zhao, M., Deng, J., Wang, Z. and Ding, Y. (2018): Enhanced Heat Transfer in a Parabolic Trough Solar Receiver by Inserting Rods and using Molten Salt as Heat Transfer Fluid, Applied Energy, Vol. 220, pp. 337-350. https://doi.org/10.1016/j.apenergy.2018.03.091

Das, S. K., Theisen, N. P. and Roetzel, W. (2003): Temperature Dependence of Thermal Conductivity Enhancement for Nanofluid, Journal of Heat Transfer-Trans ASME, Vol. 125, pp. 567-574.

https://doi.org/10.1115/1.1571080

Dnyaneshwar, R. Waghole, R.M.W., Kulkarni, V.S. and Shrivastva, R.K. (2014): Experimental Investigations on Heat Transfer and Friction Factor of Silver Nanofliud in Absorber/Receiver of Parabolic Trough Collector with Wisted tape Inserts, Energy Procedia, Vol. 45, pp. 558-567.

https://doi.org/10.1016/j.egypro.2014.01.060

Duangthongsuk, W. and Wongwises, S. (2009): Heat Transfer Enhancement and Pressure Drop Characteristics of TiO2-water Nanofluid in a Double-tube Counter Flow Heat Exchanger, International Journal of Heat and Mass Transfer, Vol. 52, No. 7-8, pp. 2059-2067.

https://doi.org/10.1016/j.ijheatmasstransfer.2008.10.023

Eastman, J. A., Choi, S.U.S., Li, S. and Thompson, L.J. (1997): Enhanced Thermal Conductivity through the Development of Nanofluids. Proceedings of Symposium on Nanophase Nanocomposite Materials II, Vol. 457, pp. 3-11. https://doi.org/10.1557/PROC-457-3

Holman, J.P., Heat transfer, 2nd ed. Macgraw-Hill, Inc, 1997. 
Hong, T. K., and Yang, H. S. (2005): Study of the Enhanced Thermal Conductivity of Fe Nanofluids, Physics, Vol. 97, pp. 4-7. https://doi.org/10.1063/1.1861145

Islam, M.K., Hasanuzzaman, M. and Rahim, N.A. (2015): Modelling and Analysis on the Effect of Different Parameters on a Parabolic Trough Concentrating Solar System, RSC Advances, Vol. 5, pp. 36540-36456. https://doi.org/10.1039/C4RA12919A

Islam. M. K. (2016): Performance Analysis of Parabolic Trough Concentrated Solar System, M.Phil Thesis, University of Malaya, Malaysia.

Javadi, F.S., Saidur, R., and Kamalisarvestani, M. (2013): Investigating Performance Improvement of Solar Collectors by using Nanofluids, Renewable and Sustainable Energy Reviews, Vol. 28, pp. 232-245. https://doi.org/10.1016/j.rser.2013.06.053

Kamyar, A., Saidur, R. and Hasanuzzaman, M. (2012): Application of Computational Fluid Dynamics (CFD) for Nanofluids, International Journal of Heat and Mass Transfer, Vol. 55, No. 15-16, pp. 4104-4115. https://doi.org/10.1016/j.ijheatmasstransfer.2012.03.052

Kasaeian, A., Sokhansefat, T, Abbaspour, M. J. and Sokhansefat, M. (2012): Numerical Study of Heat Transfer Enhancement by using Al2O3/synthetic Oil Nanofluid in a Parabolic Trough Collector Tube, World Academy of Science, Engineering and Technology, Vol. 69, pp. 1154-1159.

Kasaiean, A., Sameti, M., Daneshazarian, R., Noori, Z., Adamian, A. and Ming, T. (2018): Heat Transfer Network for a Parabolic Trough Collector as a Heat Collecting Element using Nanofluid, Renewable Energy, Vol. 123, pp. 439-449. https://doi.org/10.1016/j.renene.2018.02.062

Khosravi, A., Malekan, M. and Assad, M. E. (2019): Numerical Analysis of Magnetic Field Effects on the Heat Transfer Enhancement in Ferrofluids for a Parabolic Trough Solar Collector, Renewable Energy, Vol. 134, pp. 54-63. https://doi.org/10.1016/j.renene.2018.11.015

Kole, M. and Dey, T. K. (2012): Effect of Prolonged Ultrasonication on the Thermal Conductivity of ZnOEthylene Glycol Nanofluids, Thermochimica Acta, Vol. 535, pp. 58-65.

https://doi.org/10.1016/j.tca.2012.02.016

Kwak, H. E., Shin, D. and Banerjee, D. (2010): Enhanced Sensible Heat Capacity of Molten Salt and Conventional Heat Transfer Fluid Based Nanofluid for Solar Thermal Energy Storage, ASME 2010 4th International Conference on Energy Sustainability, Vol. 2: pp. 735-739. https://doi.org/10.1115/ES2010-90295 Lenert, A. and Wang, E.N. (2012): Optimization of Nanofluid Volumetric Receivers for Solar Thermal Energy Conversion, Solar energy, Vol. 86, No. 1, pp. 253-265. https://doi.org/10.1016/j.solener.2011.09.029

Leong, K. C., Yang, C. and Murshed, S.M. S. (2006): A Model for the Thermal Conductivity of NanofluidsThe Effect of Interfacial Layer, Journal of Nanoparticle Research, Vol. 8, pp. 245-254.

https://doi.org/10.1007/s11051-005-9018-9

Lu, L., Liu, Z. H., and Xiao, H. S. (2011): Thermal Performance of an Open Thermosyphon using Nanofluids for High-temperature Evacuated Tubular Solar Collectors: Part 1: Indoor Experiment, Solar Energy, Vol. 85, No. 2, pp. 379-387. https://doi.org/10.1016/j.solener.2010.11.008

Marefati, M., Mehrpooya, M. and Shafii, M. B. (2018): Optical and Thermal Analysis of a Parabolic Trough Solar Collector for Production of Thermal Energy in Different Climates in Iran with Comparison between the Conventional Nanofluids. Journal of Cleaner Production, Vol. 175, pp. 294-313. https://doi.org/10.1016/j.jclepro.2017.12.080

O'Keeffe, G. J., Mitchell, S. L., Myers, T. G. and Cregan, V. (2018): Modelling the Efficiency of a Nanofluidbased Direct Absorption Parabolic Trough Solar Collector, Solar Energy, Vol. 159, pp. 44-54. https://doi.org/10.1016/j.solener.2017.10.066

Okonkwo, E. C., Essien, E. A., Abid, M., Kavaz, D. and Ratlamwala, T. A. (2018): Thermal Performance Analysis of a Parabolic Trough Collector using Water-based Green-synthesized Nanofluids, Solar Energy, Vol. 170, pp. 658-670. https://doi.org/10.1016/j.solener.2018.06.012

Pak, B. C., \& Cho, Y. I. (1998): Hydrodynamic and Heat Transfer Study of Dispersed Fluids with Submicron Metallic Oxide Particles. Experimental Heat Transfer, Vol. 11, pp. 151-170.

https://doi.org/10.1080/08916159808946559

Palm, S.J., Roy, G. and Nguyen, C.T. (2004): Heat Transfer Enhancement in Radial Flow Cooling System using Nanofluid, In: Proceeding of the ICHMT International Symposium of Advance Composite Heat Transfer, Norway, CHT-04-121.

Prasher, R., Bhattacharya, P. and Phelan, P.E. (2006): Brownian-motion-based Convective-Conductive Model for the Effective Thermal Conductivity of Nanofluids, Journal of Heat Transfer-Trans ASME, Vol. 128, pp. 588-595. https://doi.org/10.1115/1.2188509

Prasher, R., Phelan, P.E. and Bhattacharya, P. (2006): Effect of Aggregation Kinetics on the Thermal Conductivity of Nanoscale Colloidal Solutions (nanofluid), Nano Letters, pp. 1529-1534. https://doi.org/10.1021/n1060992s 
Roy, G., Nguyen, C.T. and Lajoie, P.R. (2004): Numerical Investigation of Laminar Flow and Heat Transfer in a Radial Flow Cooling System with the use of Nanofluids, Superlattices and Microstructures, Vol. 35, No. 3, pp. 497-511. https://doi.org/10.1016/j.spmi.2003.09.011

Saidur, R., Meng, T. C., Said, Z., Hasanuzzaman, M., and Kamyar, A. (2012): Evaluation of the Effect of Nanofluid-based Absorbers on Direct Solar Collector, International Journal of Heat and Mass Transfer, Vol. 55, No. 21-22, pp. 5899-5907. https://doi.org/10.1016/j.ijheatmasstransfer.2012.05.087

Saidur, R., Meng, T. C., Said, Z., Hasanuzzaman, M., and Kamyar, A. (2012): Evaluation of the Effect of Nanofluid-based Absorbers on Direct Solar Collector, International Journal of Heat and Mass Transfer, Vol. 55, No. 21-22, pp. 5899-5907. https://doi.org/10.1016/j.ijheatmasstransfer.2012.05.087

Sani, E., Barison, S., Pagura, C., Mercatelli, L., Sansoni, P. and Fontani, D. (2010): Carbon Nanohorns-based Nanofluids as Direct Sunlight Absorbers. Optics Express, Vol. 18, pp. 5179-5187. https://doi.org/10.1364/OE.18.005179

Sani, E., L.M., Barison, S., Pagura, C., Agresti, F., Colla, L. and Sansoni, P. (2011): Potential of Carbon Nanohorn-based Suspensions for Solar Thermal Collectors, Solar Energy Materials and Solar Cells, Vol. 95, No. 11, pp. 2994-3000. https://doi.org/10.1016/j.solmat.2011.06.011

Sarkar, J. (2011): A Critical Review on Convective Heat Transfer Correlations of Nanofluids, Renewable and Sustainable Energy Review, Vol. 15, No. 6, pp. 3271-3277. https://doi.org/10.1016/j.rser.2011.04.025

Shahrul, I. M., Mahbubul, I. M., Saidur, R., Khaleduzzaman, S. S., Sabri, M. F. M., \& Rahman, M. M. (2014): Effectiveness Study of a Shell and Tube Heat Exchanger Operated with Nanofluids at Different Mass Flow Rates. Numerical Heat Transfer, Part A: Applications: Vol. 65, No. 7, pp. 699-713. https://doi.org/10.1080/10407782.2013.846196

Sokhansefat, T., Kasaeian, A. B., and Kowsary, F. (2014): Heat Transfer Enhancement in Parabolic Trough Collector Tube using Al2O3/synthetic Oil Nanofluid, Renewable and Sustainable Energy Reviews, Vol. 33, pp. 636-644. https://doi.org/10.1016/j.rser.2014.02.028

T.VP, Thermion VP-1 Update.qxd. www.therminol.com/pages/bulletins/therminol_vp1.pdf, Retrieved on $13 / 03 / 2014$.

Tagle-Salazar, P. D., Nigam, K. D. P. and Rivera-Solorio, C. I. (2018): Heat Transfer Model for Thermal Performance Analysis of Parabolic Trough Solar Collectors using Nanofluids, Renewable Energy, Vol. 125, pp. 334-343. https://doi.org/10.1016/j.renene.2018.02.069

Taylor, R. A., Phelan, P. E., Otanicar, T. P., Adrian, R., and Prasher, R. (2011): Nanofluid Optical Property Characterization: Towards Efficient Direct Absorption Solar Collectors, Nanoscale Research Letter, Vol. 6, No. 1, pp. 1-11. https://doi.org/10.1186/1556-276X-6-225

Timofeeva, E.V., Smith, D. S., Yu, W., France, D. M., Singh, D. and Routbo, J. L. (2010): Particle Size and Interfacial Effects on Thermo-physical and Heat Transfer Characteristics of Water-based $\alpha$-SiC Nanofluids, Nanotechnology, Vol. 21, No. 21, pp. 215703. https://doi.org/10.1088/0957-4484/21/21/215703

Tsai, C.Y., Chiena, H.T., Dingb, P.P., Chanc, B., Luhd, T.Y. and Chena, P.H. (2004): Effect of Structural Character of Gold Nanoparticles in Nanofluid on Heat Pipe Thermal Performance, Materials Letter, Vol. 58, No. 9, pp. 1461-1465. https://doi.org/10.1016/j.matlet.2003.10.009

Xuan, Y. and Li Q. (2000): Heat Transfer Enhancement of Nanofluids. International Journal Heat Fluid Flow, Vol. 21, pp. 58-64. https://doi.org/10.1016/S0142-727X(99)00067-3

Xuan, Y. and Li. Q. (2003): Investigation on Convective Heat Transfer and Flow Features of Nanofluids, Journal of Heat Transfer-Transaction of ASME, Vol. 125, pp. 151-155. https://doi.org/10.1115/1.1532008

Yu, W. and Choi, S.U.S. (2003): The Role of Interfacial Layers in the Enhanced Thermal Conductivity of Nanofluids: A Renovated Maxwell Model, Journal on Nanoparticle Research, Vol. 5, pp. 167-171. https://doi.org/10.1023/A:1024438603801

Zeinali, S., Heris, M.N.E. and Etemad, S.G. (2007): Experimental Investigation of Convective Heat transfer of A12O3/water Nanofluid in Circular Tube, International Journal of Heat and Fluid Flow, Vol. 28, No. 2, pp. 203210. https://doi.org/10.1016/j.ijheatfluidflow.2006.05.001 